\title{
Calculation of Engineering waste Water Treatment Units
}

\author{
Vaganova O.I ${ }^{1}$, Smirnova Zhanna $V^{2}$, Kutepov M.M ${ }^{3}$, Semakhin E.A. ${ }^{4}$ \\ ${ }^{1}$ Minin Nizhny Novgorod State Pedagogical University (Minin University), Nizhny Novgorod, Russian Federation, \\ vaganova_o@mail.ru \\ ${ }^{2}$ Minin Nizhny Novgorod State Pedagogical University, Nizhny Novgorod, Russian Federation \\ z.v.smirnova@mininuniver.ru \\ ${ }^{3}$ Minin Nizhny Novgorod State Pedagogical University (Minin University), Nizhny Novgorod, Russian Federation, \\ lubovkutepova@mail.ru \\ ${ }^{4}$ Minin Nizhny Novgorod State Pedagogical University (Minin University), Nizhny Novgorod, Russian Federation, \\ semahinea@mail.ru
}

\begin{abstract}
The article considers the significance of te wastewater disposal system. Due to scientific and technological achievements, the construction of water disposal systems increases, which ensures decent living conditions for the population and it also helps to maintain a good state of the natural environment. The article provides a calculation example of a sewage pumping station taking into account all the normative indicators. Based on the calculation results, the pumps were chosen according to the object characteristics. The hourly capacity of the pumping station is determined.
\end{abstract}

Key words : Engineering stations, wastewater disposal, pumping stations.

\section{INTRODUCTION}

Nowadays, the value of fresh water as a natural raw material is constantly increasing. When used in everyday life and industry, water is polluted with substances of mineral and organic origin. This water is called wastewater.

Depending on the origin of wastewater, it may contain toxic substances and pathogens of various infectious diseases.

Water systems of cities and industrial enterprises are equipped with modern complexes of gravity and pressure pipelines, special structures that implement the diversion, treatment, neutralization and use of water and precipitation. Disposal systems also provide discharge and purification of rainwater and meltwater.

Scientific and technological achievements contribute to improving the level of urban life to meet the requirements of modern civilization.

The construction of wastewater systems is due to ensuring decent housing and living conditions of the population and it also helps to maintain a good state of the natural environment. The integrated development of wastewater disposal systems with treatment facilities is due to the implementation of established standards for wastewater purification when it is released into the river.
The development of a modern wastewater disposal system for domestic and industrial wastewater is of a particular importance, which provides a high degree of the environmental protection. The most significant results were obtained in the development of new technological solutions for efficient water use, wastewater disposal and treatment systems.

The premises for the successful solution to these problems are the developments that use the latest achievements of science and technology in the field of construction and reconstruction of collecting systems and treatment facilities, as well as the correct calculation when designing installations.

\section{LITERATURE REVIEW}

Treatment pumping stations are built when the terrain features do not give an opportunity to remove domestic and industrial wastewater, precipitation by gravity to the place of treatment. These stations must be built if the depth of sewers exceeds 4-8 $\mathrm{m}$ (depending on the soil).

It is most appropriate to locate treatment pumping stations on free territories near industrial enterprises, warehouses and green areas.

The composition of structures, their design features, type and number of main and auxiliary equipment were determined based on the principles of integrated use of water resources and nature protection, taking into account the purpose of the pumping station and its technological requirements.

Along with providing the pressure and supply provided by the water disposal schedule, the design of the pumping station took into account the need to ensure the reliability and a certain degree of trouble-free operation, sufficient ease of operation at the lowest cost for its construction and operation. Standard products and construction materials were used in the design [2].

We have to study the hourly capacity of the station at different day times and the operating mode of the pumping station.

\section{RESULT AND DISCUSSION}


This study involves a pumping unit according to the design task of calculating the pump head pressure. The installation diagram of the water supply pumping station is shown in figure 1.

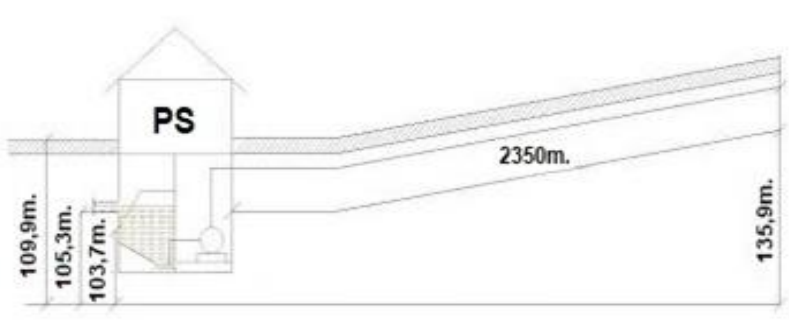

Figure 1: The installation diagram of a pumping station

Knowing the height of the foundation installation, we will make the following calculations:

Design pressure.

HSPS $=($ ZPUMPINGS-ZP $)+$ hPS + hPS-PUMPINGS

$\mathrm{hPS}=2 \mathrm{~m}$

hPS-PUMPINGS $=1,2 \cdot \mathrm{S} 0 \cdot$ Lhead pr. $\cdot \mathrm{Q} 2$

$\mathrm{V} \approx 1 \mathrm{~m} / \mathrm{sec}$

According to Shevelev's tables, we accept:

$\mathrm{Q}=136 \mathrm{l} / \mathrm{sec}, \mathrm{V}=1,09 \mathrm{~m} / \mathrm{sec}, \mathrm{d}=400 \mathrm{~mm}$,

accordingly, $\mathrm{S} 0=0.2189$

Knowing the height of the foundation installation, we will make the following calculations:

Design pressure.

HSPS $=($ ZPUMPINGS-ZP $)+$ hPS + hPS-PUMPINGS

$\mathrm{hPS}=2 \mathrm{~m}$

hPS-PUMPINGS $=1,2 \cdot \mathrm{S} 0 \cdot$ Lhead pr. $\cdot \mathrm{Q} 2$

$\mathrm{V} \approx 1 \mathrm{~m} / \mathrm{sec}$

According to Shevelev's tables, we accept:

$\mathrm{Q}=136 \mathrm{l} / \mathrm{sec}, \mathrm{V}=1,09 \mathrm{~m} / \mathrm{sec}, \mathrm{d}=400 \mathrm{~mm}$,

accordingly, $\mathrm{S} 0=0.2189$

hP.S.- PUMPINGS $=1,2 \cdot 0,2189 \cdot 2350 \cdot 0,13542=11,32 \mathrm{~m}$.

HSPS $=(135,9-(105,3-1,6))+2+11,32=45,52 \mathrm{~m}$.

The next step in the calculation is the distribution of the average daily consumption of domestic wastewater as a percentage by hour of the day, depending on the hourly coefficient of variation [4]. In accordance with the specified pumping station capacity and the coefficient of hourly variation, hourly consumptions are determined. The values are shown in table 1.

Table 1: Hourly coefficient of variation defines hourly consumption.

\begin{tabular}{|c|c|c|c|c|c|c|}
\hline 13 & $\mathrm{C}=1,4$ & $\begin{array}{c}\text { Flow } \\
\text { rate } \\
\mathrm{m} 3 / \mathrm{h}\end{array}$ & $\begin{array}{c}\text { Hours } \\
\text { of the } \\
\text { day }\end{array}$ & $\mathrm{C}=1,4$ & $\begin{array}{c}\text { Flow } \\
\text { rate } \\
\mathrm{m} 3 / \mathrm{h}\end{array}$ & 13 \\
\hline $0-1$ & 4,2 & 491,4 & $12-13$ & 5,85 & 684,45 & $0-1$ \\
\hline $1-2$ & 3,7 & 432,9 & $13-14$ & 5,35 & 625,95 & $1-2$ \\
\hline $2-3$ & 2,7 & 315,9 & $14-15$ & 5,25 & 614,25 & $2-3$ \\
\hline $3-4$ & 2,5 & 292,5 & $15-16$ & 4,6 & 538,2 & $3-4$ \\
\hline $4-5$ & 2,65 & 310,05 & $16-17$ & 4,4 & 514,8 & $4-5$ \\
\hline $5-6$ & 2,2 & 257,4 & $17-18$ & 4,6 & 538,2 & $5-6$ \\
\hline $6-7$ & 2,25 & 263,25 & $18-19$ & 4,6 & 538,2 & $6-7$ \\
\hline
\end{tabular}

\begin{tabular}{|c|c|c|c|c|c|c|}
$7-8$ & 3,2 & 374,4 & $19-20$ & 4,9 & 573,3 & $7-8$ \\
\hline $8-9$ & 3,9 & 456,3 & $20-21$ & 4,6 & 538,2 & $8-9$ \\
\hline $9-10$ & 4,5 & 526,5 & $21-22$ & 4,7 & 549,9 & $9-10$ \\
\hline $10-11$ & 5,1 & 596,7 & $22-23$ & 4,5 & 526,9 & $10-11$ \\
\hline $11-12$ & 5,35 & 625,95 & $23-24$ & 4,4 & 514,8 & $11-12$ \\
\hline
\end{tabular}

3.1. Determining the hourly output of a pumping station The flow of wastewater to the pumping station determines the mode of its operation. In conditions of unstable flow, to ensure the decent operation of pumps at sewage stations, receiving tanks of sufficient capacity are arranged, which allows to accumulate a certain amount of wastewater for some time when the pumps are not working. When they are turned on, pump out the accumulated water to treatment facilities [5].

Recalculate the pump station head pressure by the maximum hourly flow rate:

$$
\begin{gathered}
\mathrm{Q}=684,45 \mathrm{~m} 3 / \mathrm{h} . \\
\mathrm{Q}=190 \mathrm{l} / \mathrm{sec}, \mathrm{V}=1,5 \mathrm{~m} / \mathrm{sec}, \mathrm{d}=400 \mathrm{~mm} \text {, accordingly } \\
\text { S0=0,2189 } \\
\text { HP.S.- PUMPINGS=1,2 } 0,2189 \cdot 2350 \cdot \\
\text { 0,1901252=22,31 } \mathrm{m} . \\
\text { HSPS=(135,9-(105,3-1,6))+2+22,31= } 56,51 \mathrm{~m} . \\
\mathrm{Q}=684.45 .
\end{gathered}
$$

3.2. Determining the number of main and auxiliary pumps We determine the number of main and auxiliary pumps depending on the category of the sewage pump stations.

Determining the number of residents:

$$
N=\frac{7300 \cdot 1000}{400}=18250 \text { people }
$$

It means that the SPS has the 2nd reliability category. Let us determine the approximate number of main pumps based on table 2 .

Table 2: Parameters of the working pumps

\begin{tabular}{|c|c|c|c|}
\hline $\mathrm{Q}, \mathrm{m} 3 / \mathrm{h}$ & K 20/30,Dk=162mm & 3 pumps & \\
\hline $\mathrm{H}, \mathrm{m}$ & $\mathrm{N}$ & $\%$ & \\
\hline 0 & 33,9 & 2,7 & 0 \\
21,6 & 34,8 & 4,8 & 42 \\
43,2 & 33,4 & 6,6 & 58 \\
64,8 & 29,9 & 8,1 & 65 \\
86,4 & 25 & 9,3 & 64 \\
108 & 18,8 & 9,9 & 57 \\
118,8 & 15,9 & 9,6 & 53 \\
\hline \multicolumn{2}{|c|}{$Q$ max hour } \\
$n=\frac{684,45}{257,4} \approx 3$ \\
M min hour
\end{tabular}

3.3. Pump supply determination for paralleled and single operation, and selection of main and auxiliary pumps

Thus: 
International Journal of Emerging Trends in Engineering Research, 8(5), May 2020, 1556 - 1560

$$
\begin{aligned}
Q_{\text {hour }} & =\frac{684,45 \cdot 1,18}{3}=269,217 \mathrm{~m}^{3} / \mathrm{h} \\
Q_{\text {par }_{\text {hour }}} & =\frac{684,45}{3}=228,15 \mathrm{~m}^{3} / \mathrm{h}
\end{aligned}
$$

Pump CM 200 - 150 - 500/4 was chosen.

The letters in the brand indicate: $\mathrm{C}$ - mixing, M-mass. The numbers indicate: 200 - the diameter of the suction pipe, 150-the diameter of the pressure pipe, 500-the diameter of the impeller. Pump CM is single-stage, with one-way water supply. The unit consists of a pump and an electric motor connected by an elastic coupling and mounted on a common frame [9.10].

In addition to main pumps, sewage-pumping stations have auxiliary units installed, depending on the category. According to Construction Standards and Regulations 2.04.03.-85 [1], two auxiliary pumps are installed on sewerage external networks and structures of the second category and four working pumps size of the alloying bath decrease with increasing speed of laser alloying to $\mathrm{V}=1.0 \div 1.2 \mathrm{~cm} / \mathrm{s}$ and the structure becomes more homogeneous (Fig. 1, b). The greater uniformity of the structure is explained by more intense mixing, but in such a short time it is unlikely for the diffusion mechanism, although it is real for the convective one.

In conclusion, we would like to say that the processing speed during laser alloying influence on the distribution of the legrant in the alloy bath and regulates the mixing mechanism, including both diffusion and convection.

\subsection{Pumping station construction and the pressure loss in} it.

Let us consider the approximate structure of a pumping station, as a rule, they are built combined with the receiving tank according to the layout, figure 2 .

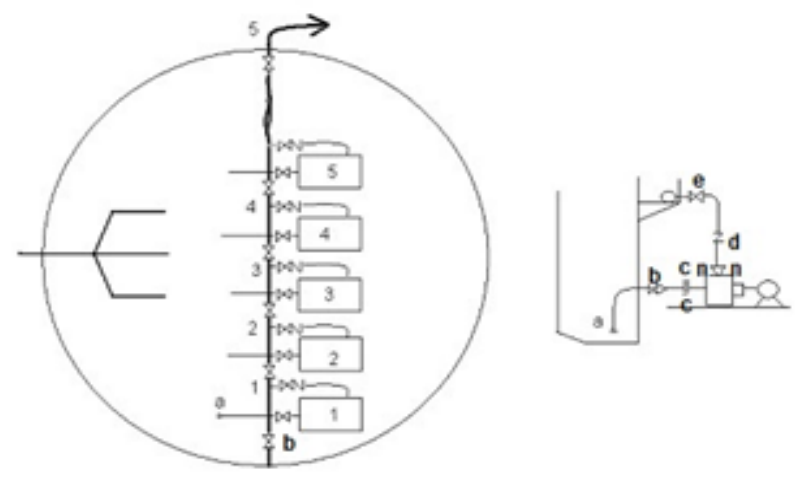

Figure 2: Pump station diagram

The losses at the pumping station consist of losses at local resistances, tees, valves, turns, constrictions and extensions, and the losses along the length we take to be approximately zero [7].

Electric-welded steel pipes are used for pumping stations. Pipe diameters are determined based on economic speeds. For the pressure pipeline, it is $1.5-2.5 \mathrm{~m} / \mathrm{s}$, and for the suction $0.7-1.5$ $\mathrm{m} / \mathrm{s}$, table 3 .

Table 3: Indicators of the pumping station by the number of the studied area

\begin{tabular}{|c|c|c|c|}
\hline $\begin{array}{c}\text { Section } \\
\text { number }\end{array}$ & Q 1/sec & V m/sec & D mm \\
\hline a-b & 63,38 & 1,19 & 250 \\
\hline c-c & 63,38 & 2,02 & 200 \\
\hline n-n & 63,38 & 3,59 & 150 \\
\hline d-e & 63,38 & 1,84 & 200 \\
\hline $1-2$ & 63,38 & 0,468 & 400 \\
\hline $2-3$ & 126,75 & 0,94 & 400 \\
\hline $3-4$ & 190,13 & 1,42 & 400 \\
\hline
\end{tabular}

Then losses on local resistances are calculated as follows:

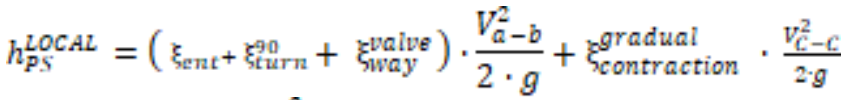

$$
\begin{aligned}
& +\xi_{\text {enlargement }}^{\text {gradual }} \cdot \frac{V_{n-n}^{2}}{2 \cdot g}+\left(\xi_{\text {per }}+\xi_{\text {turn }}^{90}+\xi_{\text {way }}^{\text {valve }}+\xi_{\text {tee }}^{\text {turn }}\right) \\
& \cdot \frac{V_{d-e}^{2}}{2 \cdot g}+\xi_{\text {way }}^{\text {valve }} \cdot \frac{V_{1-2}^{2}}{2 \cdot g}+\xi_{\text {turn }}^{\text {tee }} \cdot \frac{V_{d-g}^{2}}{2 \cdot g}+\xi_{\text {way }}^{\text {valve }} \cdot \frac{V_{2-g}^{2}}{2 \cdot g}+\xi_{\text {turn }}^{\text {tee }} \cdot \frac{V_{d-g}^{2}}{2 \cdot g}+ \\
& \left(3 \cdot \xi_{\text {way }}^{\text {valve }}+2 \cdot \xi_{\text {way }}^{\text {tee }}+2 \cdot \xi_{\text {turn }}^{90}\right) \cdot \frac{V_{d-4}^{2}}{2 \cdot g} \\
& \xi_{\text {ent }}=0,5 \\
& \xi_{\text {turn }}^{90}=0,5 \\
& \xi_{\text {valve }}^{\text {waterway }}=0,1 \\
& \xi_{\text {contraction }}^{\text {gradual }}=0,1 \\
& \xi_{\text {enlargement }}^{\text {gradual }}=0,25 \\
& \xi_{\text {per }}=1,7 \\
& \xi_{\text {turn }}^{\text {tee }}=1,5 \\
& \xi_{w a y}^{t e e}=0,1
\end{aligned}
$$

HPS.LOCAL $=1,31 \mathrm{M}$.

Exact pressure head at SPS.

$\mathrm{H}_{\mathrm{SPS}}=(135,9-(105,9-1,6))+1,31+22,31=55,82 \mathrm{~m}$.

\subsection{Adjusting pump characteristics}

Factory specifications of pumps often do not provide the parameters required by the calculation. In these cases, they adjust the characteristics by changing the rotation speed or reducing the wheel diameters (by cutting).

Let us create an equation for the network operation.

$$
\mathrm{H}_{\text {WATERSYSTEMS }}=\mathrm{H}_{\mathrm{GEOM}}+\mathrm{h}_{\text {PIPELINE }}+\mathrm{h}_{\mathrm{PS}} \text {. }
$$$$
\mathrm{H}_{\mathrm{GEOM}}=135,9-(105,3-1,6)=32,2 \mathrm{~m} \text {. }
$$

$\mathrm{H}_{\mathrm{PIPELINE}}=1,2 \cdot \mathrm{S} 0 \cdot \mathrm{L} \cdot \mathrm{Q} 2=1,2 \cdot 0,2189 \cdot 2350 * \mathrm{Q} 2=$ $617,298 \cdot \mathrm{Q} 2$

$$
\mathrm{h}_{\mathrm{PS}}=\mathrm{S}_{\mathrm{PS}} \cdot \mathrm{Q}_{2}
$$


International Journal of Emerging Trends in Engineering Research, 8(5), May 2020, 1556 - 1560

$$
S_{P S}=\frac{h_{P S}}{Q_{M A X}^{2}}=\frac{1,31}{\left(\frac{684,45}{3600}\right)^{2}}=36,23
$$

$\mathrm{H}_{\mathrm{WATERSYSTEMS}}=32,2+(36,23+617,298) \cdot \mathrm{Q}^{2}=32,2+653,53 \cdot$ Q2

Plot the pipeline characteristic based on the studied pump parameters:

Table 4: Pump operations working in the pipeline system

\begin{tabular}{|c|c|c|c|c|c|}
\hline \multicolumn{2}{|c|}{ 1. Pump } & \multicolumn{2}{c|}{ 2. Pump } & \multicolumn{2}{c|}{ 3. } \\
\hline Q & H & Q & H & Q & H \\
\hline 120 & 76 & 360 & 76 & 240 & 76 \\
\hline 180 & 74 & 540 & 74 & 360 & 74 \\
\hline 240 & 72 & 720 & 72 & 480 & 72 \\
\hline 300 & 69 & 900 & 69 & 600 & 69 \\
\hline 360 & 65 & 1080 & 65 & 720 & 65 \\
\hline
\end{tabular}

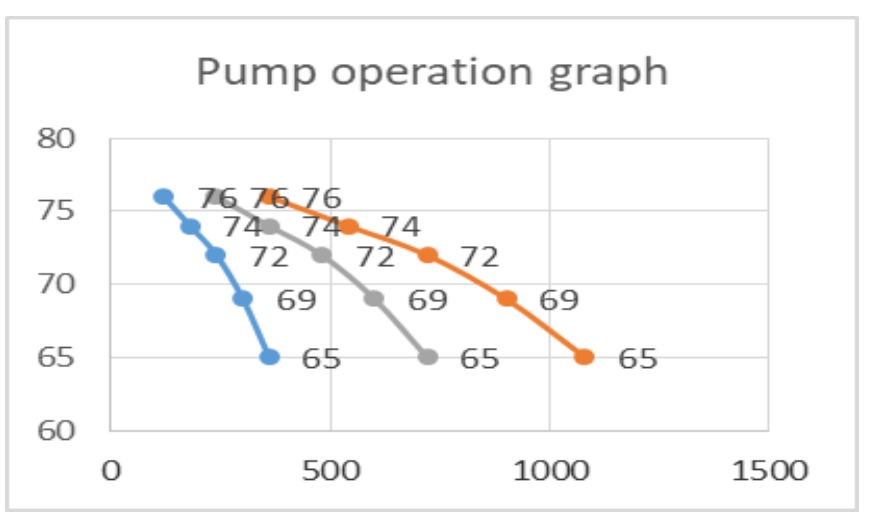

Figure 3: Shows what flow can be provided by 3 Pumps CM 200-150-400/4 when working in the pipeline system.

They provide more than the calculated flow, so it is necessary to optimize the operation of pumps by reducing the wheel diameter [11,12].

When cutting, i.e. when reducing the diameter of the impeller, the pump parameters change according to the following dependencies:

or where Q, H and D are the water supply, head pressure and diameter of the pump wheel before cutting;

QCUT, HCUT and DCUT are the same but after cutting the pump wheel.

Pump CM 200-150-400/4 characteristics with wheel diameter $\mathrm{D}=400 \mathrm{~mm}$ and $\mathrm{n}=1450 \mathrm{rpm}$

We calculate the speed coefficient ns of the pump.

When $\eta \mathrm{MAX}=63 \%, \mathrm{Q}=390 \mathrm{~m} 3 / \mathrm{h}$

HCUT = 55,83 m.; QCUT = 684,45/3 = 228, $18 \mathrm{m3} / \mathrm{h}$.

Pumps with this cutting ensure the necessary water flow.

\section{CONCLUSION}

Special underwater pumps equipped with automatic control are used in the SPS, which allow them to operate in automatic mode, turning on only when the liquid reaches a certain level (set by the operator). The maximum permissible depth of each pump is its own and it is regulated by the requirements of the manufacturer. It is very important to comply with them, since this is what largely determines the ability of the SPS to work smoothly and with good capacity, ensuring rapid pumping of sewage.

In the study, we calculated the parameters required when selecting a pump for installing a wastewater treatment system for a specific project task.

\section{REFERENCES}

1. Abramova N.S., Vaganova O.I., Smirnova Zh.V., Chaikina Z.V., Kaznacheeva S.N. Formation of socio-economic culture of future engineers//B сборнике: Lecture Notes in Networks and Systems. Growth Poles of the Global Economy: Emergence, Changes and Future Perspectives. Plekhanov Russian University of Economics. Luxembourg, 2020. C. 1041-1047. https://doi.org/10.1007/978-3-030-15160-7_104

2. Voron, J. Education and Sociocybernetics, Azimuth of scientific research (Azimuth of scientific research: Economics and management), 6, 3 (20), 289-297.

3. Gruzdeva K. E., Smirnova Zh.V., Cherney O. T. Improving the management system of services in housing and communal services//Innovative economy: prospects for development and improvement. 2020. no. 1 (43). pp. 18-24

4. Gruzdeva M. L., Smirnova Z.V., Tukenova N. I. Internet services application in teaching technology//Bulletin of Minin University. 2018. Vol. 6. No. 1 (22). P. 8. https://doi.org/10.26795/2307-1281-2018-6-1-8

5. Donetskova, O. Y. (2019). Modernization of the modern education system in Russia. Baltic humanitarian magazine, 8 , 2 (27), 37-39. (in Russia.).

6. Kornilov Y.V., Ivanov I.A. Computer graphics training in additional education on the basis of inverted learning technology / / Azimut of scientific research: pedagogy and psychology. 2019. Vol. 8. No. 4 (29). Pp. 111-114.

7. Mukhina M.V., Smirnova Zh.V. Housing and utility service //Collection of articles: Russian initiative developments (Initiative. Enterprise. Ingenuity). Scientific publication. Saint-Louis, Missouri, USA, 2017. p. 79.

8. Smirnova Zh.V. Engineering networks and equipment//Educational and methodological guide / Nizhny Novgorod, 2016.

9. Smirnova Zh.V., Kochnova K. A. Training of service enterprises' employees using information technologies//Vestnik of Minin University. 2019. Vol. 7. No. 1 (26). P. https://doi.org/10.26795/2307-1281-2019-7-1-5

10. Smirnova Zh.V., Mukhina M.V., Katkova O.V., Gruzdeva M.L., Chernei O.T. Network interaction as a factor of professional qualities' development of service workers//Lecture Notes in Networks and Systems (см. в книгах). 2020. Т. 87. С. 698-704.

https://doi.org/10.1007/978-3-030-29586-8_81

11. Smirnova, Zh.V., Mukhina, M.V., Kutepova, L.I., Kutepov, M.M., Vaganova, O.I.: Organization of the research activities of service majors trainees. In: Advances in Intelligent Systems and Computing, vol. 622, pp. 187-193 (2018) 
International Journal of Emerging Trends in Engineering Research, 8(5), May 2020, 1556 - 1560

https://doi.org/10.1007/978-3-319-75383-6_24

12. A.A. Sokolovsky, A.I. Zemtsov, D.I. Kovalev, E.M. Shishkov, A.A. Kazantsev Hybrid Fiber Optic Temperature Sensor Powered by Optical Radiation //International Journal of Emerging Trends in Engineering Research Volume 7, No. 12 December 2019

https://doi.org/10.30534/ijeter/2019/217122019 